\title{
The influence of legislators' endorsements in party leadership elections
}

\begin{abstract}
In the 2010 election for the post of leader of the British Labour party, almost all members of parliament (MPs) endorsed one of five leadership candidates. I investigate the effect of these endorsements on the votes cast for candidates in each Westminster constituency. I find that an MP's endorsement caused an average increase of 7.5 percentage points in the vote share of the endorsed candidate in that MP's constituency.
\end{abstract}

\section{Introduction}

Over the past twenty years, the methods used to choose party leaders in parliamentary democracies have changed. "There has been a general... trend towards granting party members greater influence in the choice of their leader" (Cross and Blais 2012,127). This has often involved a ballot of party members, which can either determine the party leader by itself or form part of a more complicated selection process involving party elites (Kenig 2009a, 437). 
- The influence of legislators' endorsements in party leadership elections

These changes in formal influence are noteworthy, and have important symbolic effects (Faucher 2014). The expansion of the selectorate to include party members has been described as a process of "democratisation" (Kenig 2009b). However, just as with democracy at the level of the nation-state, it is always possible to ask whether individual electors' decisions, though formally decisive, are in fact strongly influenced by the positions adopted by other actors. Here I ask whether the decisions of ordinary party members are influenced by the positions adopted by party elites, and more specifically whether the votes of members of constituency Labour parties were influenced by the decision of the member of parliament (MP) for that constituency to endorse one of the candidates in the 2010 Labour leadership election.

Two features of this election make it possible to identify the effect of MP endorsements.

First, Labour released "surprisingly rich data" (Pemberton and Wickham-Jones 2013, 711) showing the distribution of first-preference votes in each Westminster constituency. Although MPs' endorsements can have effects outside of their own constituency, we would expect the effects of an MPs' endorsement to be concentrated within the seat they represent. It is therefore possible to identify the effects of endorsement not through averaging across multiple elections (the strategy adopted by Dominguez (2011) and Kousser et al. (2015)), but by averaging across multiple endorsements within a single election. 
- The influence of legislators' endorsements in party leadership elections

Second, Labour released information on how MPs voted. Because the election involved an electoral college where the votes of MPs and Members of the European Parliament (MEPs) were given equal weight to the votes of party members, the party decided to make these votes public. Additionally, because the election was held under the Alternative Vote system, the party published not just details on the first preference votes (as they had done for the constituencies), but all expressed preferences. This extra information is invaluable, because it allows us to disentangle the effects of endorsement from the effects of other candidate characteristics which might both make candidates more likely to attract votes, and more likely to attract endorsements. The intuition (described more fully below) is that when we model the effects of endorsement, we must control for other characteristics, and there is no better control than knowing which candidate was sufficiently attractive to come second in the MP's preference ranking (rather than third, fourth, or fifth).

\section{Theory and practice of endorsements}

Endorsements - public statements of support for candidates - can serve as signals for uninformed utility-maximizing voters who are unsure about candidate position (Grofman and Norrander 1990) or quality (Wittman 2007), or as inputs for voting heuristics ("vote for the candidate someone you trust endorses") for satisficing voters (Lau and Redlawsk 2001; McDermott 2006). Endorsements can 
- The influence of legislators' endorsements in party leadership elections

have positive or negative effects on candidates' vote shares. Utility-maximizing voters unsure about a candidate's position may be less likely to vote for a candidate if the candidate is endorsed by someone who is ideologically far from the voter (Grofman and Norrander 1990). Alternately, satisficing voters may adopt a negative heuristic ("do not vote for the candidate endorsed by those you dislike or distrust") (Arceneaux and Kolodny 2009,757).

Endorsements thus cause changes in vote share primarily by changing how voters think about candidates. Other, broader effects of endorsement have also been discussed in the literature. Endorsements from individuals or organisations may be valuable because they permit individuals or organisations to provide resources to candidates, either financial (membership organisations who endorse may also donate), organisational (organisations may provide help in campaigning), or informational (organisations may share information on their membership: Jobson and Wickham-Jones (2011), 328-329).

Although knowing the mechanism through which endorsements operate is important, it is also important to have some idea of the magnitude of the effect of endorsements. Estimating the causal effect of endorsements is difficult, because endorsement may be associated with other characteristics which make candidates win votes. In an ingenious paper, Kousser et al. (2015) examine the effect of endorsement upon the success of candidates in California's top-two primary elections. They are able to identify the effect of endorsement because they have records of the internal party votes which determined the endorsements. Using a 
- The influence of legislators' endorsements in party leadership elections

regression discontinuity design, they find that candidates who were just successful in obtaining the party's endorsement on average receive vote shares that are ten percentage points higher than candidates who narrowly failed to obtain the party's endorsement. In earlier work, Masket has shown that endorsement effects under the previous system used for primary elections were similar in magnitude. On the basis of such effects, Masket has concluded that "informal party organizations control nominations" (Masket 2009).

There are, however, reasons to think that the value of endorsements in closed party primaries held to elect party leaders will be smaller than the value of endorsements in open party primaries of the type found in the United States. First, voters in closed party elections are often political sophisticates. Most people do not join political parties: in the UK, only about one in a hundred do so (Van Biezen, Mair, and Poguntke 2012). Generally, party identifiers are more knowledgeable about politics (Milner 2006); it would be surprising if party members were not more knowledgeable still. Party members may have very good information about candidate position and quality, and may be able to dispense with heuristics. Consequently, the effects of endorsement may be limited.

Second, the candidates in leadership elections are often well-known. Often, candidates have held important ministerial positions and are associated with different factions within their party. As such, their ideological positions are often betterknown than those of their would-be endorsers, who may "just" be MPs. 
- The influence of legislators' endorsements in party leadership elections

There are, therefore, reasons to be skeptical that party elites, by endorsing candidates, can substantially alter the decisions of ordinary party members. However, party elites may be able to change the outcome in a close election - such as the Labour leadership election of 2010.

\section{The 2010 Labour leadership election}

Following the Labour party's defeat in the general election of May 2010, Gordon Brown resigned as party leader, triggering a leadership election. The system used to select the new leader was complicated. In order to stand as a candidate for the leadership, MPs required the support of $12.5 \%$ of Labour MPs, or 33 nominations. After some debate (Bale 2015, 13), the party's executive committee set a deadline of June 9th for aspiring candidates to collect these nominations. In the end, five candidates secured enough nominations: David Miliband (81), Ed Miliband (63), Ed Balls, Andy Burnham, and Diane Abbott (33 each). Abbott only secured the necessary nominations thanks to (strategic) nominations from supporters of David Miliband (Bale 2015, 7).

In order to win the election, candidates needed to secure votes in a tripartite electoral college composed of three equally-weighted groups:

- MPs and MEPs

- constituency Labour parties and their analogues 
- The influence of legislators' endorsements in party leadership elections

- levy-paying members of trade unions and other affiliated organisations ${ }^{[]}$

Voters in each group voted using the Alternative Vote system. Ballots were sent out at the start of September, and the result was announced on the 25th September.

\subsection{MPs and MEPs}

253 of 258 MPs, and all 13 MEPs, voted in the election. ${ }^{\text {B }}$ Almost all MPs who voted had previously endorsed candidates (248 of 253). These endorsements were made public on the Labour party website, and collected by the unofficial party website Labourlist.org. Thirteen MPs ended up giving their first preference to a different candidate from the one they had endorsed. Eight of these MPs switched to a candidate that was eventually more successful. In some cases this was because MPs originally endorsed individuals in order to ensure that they would have enough nominations to become candidates.

Although MPs' first preference were, as a result, largely predictable, their remaining preferences were illuminating. $196 \mathrm{MPs}$ and MEPs expressed a second prefer-

1 For the role of trade unions in the election, see Jobson and Wickham-Jones (2011).

2 Former leader Gordon Brown, acting leader Harriett Harman, chief whip Nick Brown, and chairman of the parliamentary party Tony Lloyd did not vote for reasons of propriety. Eric Illsley MP, elected in 2010 as a Labour MP, was prevented from voting, as he had been suspended from the party after having been found guilty of false accounting.

3 See Perry, David "New Labour leader to be named at rally", Aberdeen Press and fournal, 24th September 2010. 
- The influence of legislators' endorsements in party leadership elections

ence; 141 a third preference; and 119 a fourth preference. These preferences seem to be sincere in the sense that no MP or MEP seems to have reversed the order of two candidates, such that they really preferred the candidate they ranked lower.

It is harder to argue that the preferences are sincere in the stronger sense that MPs were genuinely indifferent between candidates for whom they expressed no relative preference. For example: $31 \mathrm{MPs}$ put David Miliband as their first preference, but expressed no preference over the remaining candidates. It seems unlikely that these MPs were genuinely indifferent between Ed Miliband and Diane Abbott. Rather, it seems more likely that these MPs realised that their second preferences would only matter if David Miliband was not amongst the top two candidates, which was unlikely.

On the other hand, some MPs did express preferences which did display disregard for the likely outcome. Graeme Morrice gave his first preference to Ed Miliband, and his fourth preference to Diane Abbott. As Morrice must have known, it would have been extremely unlikely for three candidates (including Ed Miliband) to have been eliminated before Abbott.

\subsection{Constituency parties}

What made this leadership election novel was the party's decision to publish the results of the votes in different constituency Labour parties (CLPs) or equivalents. Each of the 632 mainland Westminster constituencies has a CLP, except 
- The influence of legislators' endorsements in party leadership elections

that Orkney and Shetland have one CLP each despite forming part of the same Westminster constituency, and three organisations (party head office, Labour International, and the Labour Party in Northern Ireland) also counted as CLPs for the purpose of the election.

In total, 176464 ballot papers were distributed to CLPs in Westminster constituencies, and 126631 votes were cast, for a turnout of $71.8 \%$. The average number of votes cast in CLPs with a sitting Labour MP was slightly higher than the number of votes cast in CLPs without a Labour MP (245 as compared to 169).

Although the results were released at the level of the CLP, CLPs as such were not required to play a role in the election. However, almost 400 CLPs decided to officially nominate a candidate during the campaign period. Because the decisions of CLPs to nominate candidates came after MPs' decisions to nominate candidates, CLP endorsements should therefore be seen as a possible consequence of MPs' endorsement, and as such should not be controlled for.

\subsection{The effects of endorsement}

In a contest characterised by early and prominent endorsement decisions, it seems plausible that party members' votes will be in some way influenced by MPs' endorsements - at least in the aggregate. Yet what I am interested in is the effect of MPs' endorsements on party members in their own constituencies, rather than the aggregate effect of having garnered endorsements from so many MPs. Is it 
- The influence of legislators' endorsements in party leadership elections

reasonable to expect MPs' endorsements to matter to their own CLP, either on a heuristic or signalling account of endorsements?

Recall that on the signalling account, voters react positively to signals from ideologically proximate endorsers. Since MPs must be chosen as prospective parliamentary candidates by their CLP, it is likely that CLP members and MPs are ideologically proximate. On the heuristic account, voters react positively to endorsements from those they evaluate positively. CLP members are likely to trust endorsements from MPs they originally selected to contest the seat. Thus, on either account, there are reasons to think endorsements will matter.

\section{Analysis}

A first approximation of the impact of endorsement comes from comparing the share of the first preference vote received by each candidate in constituencies in which they were endorsed by the sitting MP, with their share of the vote in constituencies in which they did not receive an endorsement, either because there was no sitting Labour MP, or because the sitting Labour MP did not endorse any candidate, or because the sitting Labour MP endorsed a different candidate.

This comparison is plotted in Figure 1. Every candidate did better in constituencies where they received an endorsement. The average effect was around 1o percent, with Diane Abbott receiving a smaller benefit from endorsements, and Andy 
- The influence of legislators' endorsements in party leadership elections

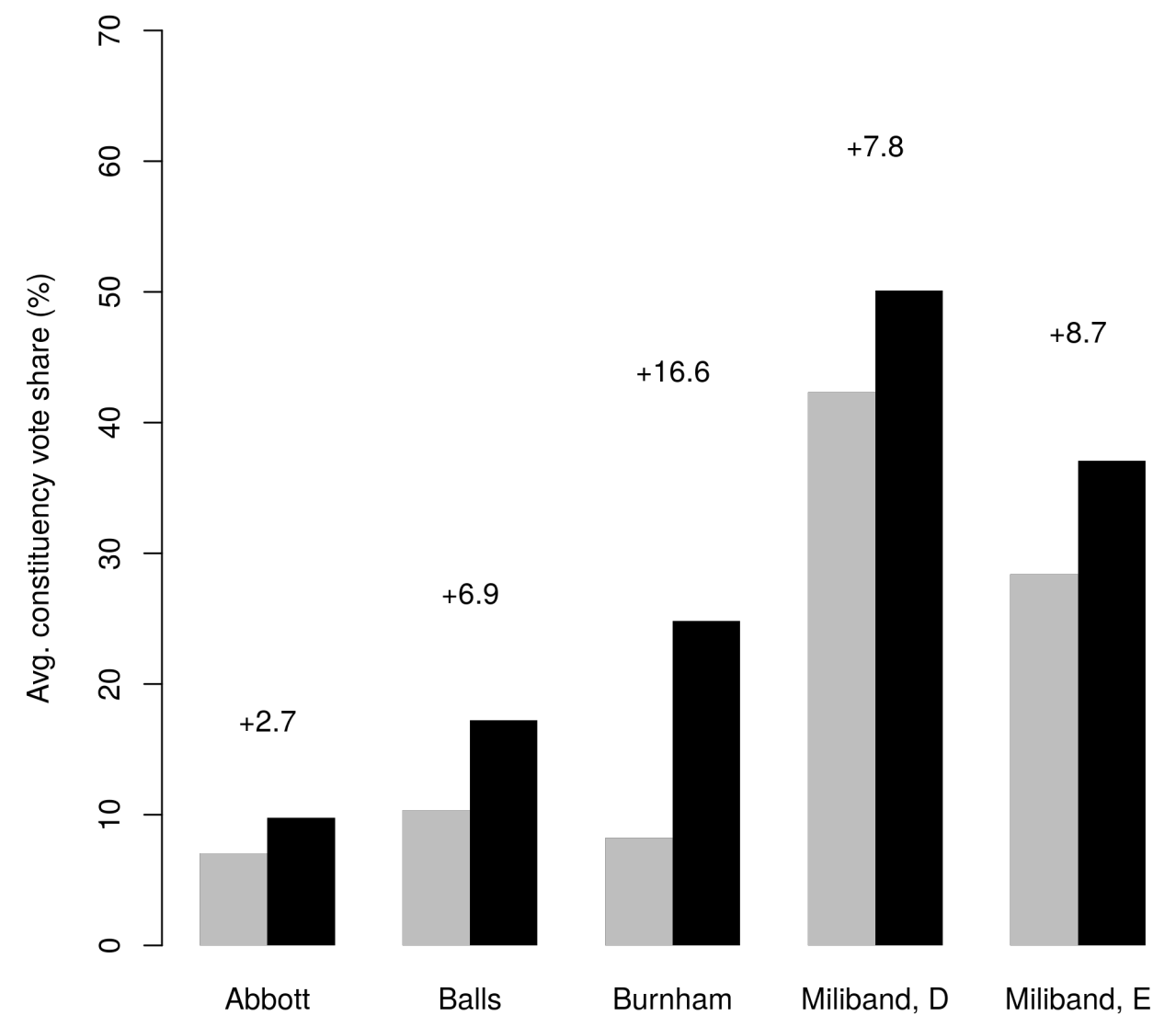

Figure 1. Impact of endorsement by sitting MP on candidate vote share. 
- The influence of legislators' endorsements in party leadership elections

Burnham a larger benefit. At first glance, therefore, the impact of endorsements seems large.

However, this comparison may be misleading, because MPs' decisions to endorse candidates may be based on factors which also affect how CLPs vote. The following example illustrates this using just two candidates.

Suppose an MP is deciding which of two candidates (A and B) she will endorse. She scores each of the candidates, and awards them "scores". She endorses the candidate with the higher score.

Suppose now that members of a constituency party are deciding which candidate to vote for. They too score the candidates, and award them identical scores as the MP.

Suppose further that this happens across a number of constituencies, and that researchers - lacking information on the scores awarded to the two candidates - attempt to model the decision of members in the constituency to vote for candidate A using a logistic regression model with a sole dummy variable recording whether or not the MP endorsed candidate A. With this model, researchers will find a strong positive effect of endorsement, but this effect will be spurious, because there is an omitted variable, namely the scores awarded by either the MP or the party members. By construction, these are the same, and so either can be included. 
- The influence of legislators' endorsements in party leadership elections

The "obvious" answer is to include the scores awarded by party members in the model. However, such scores are rarely available. The "scores" of endorsing actors are sometimes available, and if these are identical to or highly correlated with the scores of party members then they too can be used to recover the effect of endorsement. For example: in Kousser et al. (2015), the votes cast for each party in internal party committees could be used as if they were scores, and had a regression discontinuity design not been possible the authors could have inserted the difference in votes for each candidate in a more standard regression model.

In the present case, we do not have access to MPs' "scores". But we do have access to MPs' preference ranking over the candidates, which can be taken as a discretised version of the scores that MPs might have assigned. Including these preference rankings in the model thus brings us much closer to recovering the true value of endorsement. On its own, it is not sufficient, and below I discuss other variables that can be included to improve the model. But (a) since much of the concern in evaluating the effects of endorsement has concerned valence characteristics (candidate "quality"), evaluations of which are, by definition, similar across voters irrespective of their position, and (b) since MPs' ideological stances are likely to be similar to the ideological stances of their respective constituency parties, a model including these preference structures is much more likely to recover the true effect of endorsement.

We must therefore control for other characteristics which might make MPs (and CLPs) more likely to endorse (vote for) candidates. One obvious characteristic 
- The influence of legislators' endorsements in party leadership elections

is the position of the constituency party along the primary dimensions of party competition in the UK, namely taxation and Euroskepticism. Unfortunately, there are no measures of the opinion of constituency parties, and so I use measures of opinion at the constituency level. The measures of opinion are taken from Hanretty (2014) and Hanretty, Lauderdale, and Vivyan (2014), which are in turn based upon questions found in the British Election Study. Measures of preferences over taxation/public spending are on a scale from zero to ten, where zero indicates that government should cut taxes a lot and spend much less on health and social services, and ten indicates that governments should raise taxes a lot and spend much more on health and social services (mean $=6.13 ; \mathrm{SD}=0.28$ ). Measures of preferences over Europe estimate the percentage in each constituency that disapprove of Britain's membership of the European Union (mean $=48.63 ; \mathrm{SD}=8.02$ ).

A second characteristic is the nature of electoral competition in the constituency. Party members in constituencies facing a strong threat from a Conservative challenger may have different preferences over leaders than party members in constituencies which face no such threat, or a threat from the more centrist Liberal Democrats. I therefore include measures of the strength of each of the three main parties in the 2010 election, and a measure of the size of the Labour majority (or the distance from Labour to the largest party). I also include dummy variables for Scottish and Welsh constituencies, which have a different pattern of party competition. 
- The influence of legislators' endorsements in party leadership elections

The model is a multinomial logistic regression model for grouped data. The dependent variable $y_{i}$ records the number of votes cast in each constituency $i(i=$ $1, \ldots, 632)$ for each of the candidates $(j=1, \ldots 5$,$) , such that \sum y_{i}=n_{i}$, where $n_{i}$ is the number of votes cast in constituency $i$.

The counts in each constituency are modelled as a function of the probabilities $\pi_{i}$

$$
y_{i} \sim \operatorname{CAT}\left(\pi_{i}, n_{i}\right)
$$

These probabilities are in turn modelled in the usual way:

$$
\pi_{i j}=\frac{\exp \left(\beta_{j} X_{i}\right)}{\sum_{j=1}^{5} \exp \left(\beta_{j} X_{i}\right)}
$$

where $\beta_{1}=0$ for the purposes of identification.

The results of the model are shown in Table 1. Each column shows the log-odds of voting for the named candidate, as against the reference candidate (David Miliband). Thus, an endorsement for Diane Abbott in a given constituency makes party members in that constituency $e^{0.708}=2.03$ times more likely to vote for $\mathrm{Ab}$ bott. 
- The influence of legislators' endorsements in party leadership elections

Table 1

\begin{tabular}{|c|c|c|c|c|}
\hline & \multicolumn{4}{|c|}{ Dependent variable: } \\
\hline & $\begin{array}{l}\text { Abbott / Miliband D } \\
\text { (1) }\end{array}$ & $\begin{array}{l}\text { Balls / Miliband D } \\
\text { (2) }\end{array}$ & $\begin{array}{c}\text { Burnham / Miliband D } \\
\text { (3) }\end{array}$ & $\begin{array}{c}\text { Miliband E / Miliband D } \\
\text { (4) }\end{array}$ \\
\hline Conservative vote share & $-0.001(0.002)$ & $-0.003(0.002)$ & $0.007^{* *}(0.002)$ & $-0.0004(0.001)$ \\
\hline Labour vote share & $-0.018^{* * *}(0.003)$ & $-0.018^{* * *}(0.002)$ & $0.023^{* * *}(0.003)$ & $-0.011^{* * *}(0.002)$ \\
\hline Lib Dem vote share & $-0.005^{*}(0.003)$ & $-0.007^{* *}(0.002)$ & $0.023^{* * *}(0.003)$ & $-0.005^{* *}(0.002)$ \\
\hline Lab. majority/shortfall & $-0.001(0.001)$ & $0.0003(0.001)$ & $-0.002 *(0.001)$ & $-0.001(0.0004)$ \\
\hline Scottish constituency & $-0.160^{* *}(0.059)$ & $0.172^{* * *}(0.051)$ & $0.125 *(0.059)$ & $0.123^{* * *}(0.034)$ \\
\hline Welsh constituency & $-0.318^{* * *}(0.058)$ & $-0.009(0.047)$ & $-0.114 *(0.054)$ & $-0.006(0.032)$ \\
\hline Support for taxation and spending & $0.646^{* * *}(0.071)$ & $0.547^{* * *}(0.074)$ & $0.361^{* * *}(0.073)$ & $0.579^{* * *}(0.052)$ \\
\hline Euroskepticism & $-0.017^{* * *}(0.001)$ & $0.014 * * *(0.001)$ & $0.031 * * *(0.002)$ & $-0.006^{* * *}(0.001)$ \\
\hline Endorsed Abbott & $0.708^{* * *}(0.098)$ & $0.311 * *(0.096)$ & $-0.358^{* *}(0.111)$ & $0.018(0.064)$ \\
\hline Endorsed Balls & $0.247^{*}(0.096)$ & $0.798^{* * *}(0.080)$ & $0.241^{* *}(0.084)$ & $0.084(0.055)$ \\
\hline Endorsed Burnham & $0.122(0.112)$ & $0.110(0.098)$ & $0.983^{* * *}(0.087)$ & $0.154^{*}(0.063)$ \\
\hline Endorsed David Miliband & $-0.057(0.075)$ & $-0.278^{* * *}(0.068)$ & $-0.186^{* *}(0.068)$ & $-0.186^{* * *}(0.044)$ \\
\hline Endorsed Ed Miliband & $0.227^{* *}(0.073)$ & $0.110(0.068)$ & $0.080(0.068)$ & $0.385^{* * *}(0.043)$ \\
\hline 2nd pref Abbott & $0.379^{* *}(0.139)$ & $0.208(0.129)$ & $-0.088(0.144)$ & $0.268^{* *}(0.085)$ \\
\hline 2nd pref Balls & $0.019(0.061)$ & $-0.061(0.057)$ & $0.031(0.060)$ & $-0.040(0.036)$ \\
\hline 2nd pref Burnham & $-0.064(0.074)$ & $-0.155 *(0.067)$ & $-0.155^{*}(0.064)$ & $-0.024(0.042)$ \\
\hline 2nd pref David Miliband & $-0.072(0.073)$ & $-0.239^{* * *}(0.065)$ & $-0.126(0.066)$ & $-0.057(0.042)$ \\
\hline 2nd pref Ed Miliband & $-0.083(0.062)$ & $-0.201 * * *(0.057)$ & $-0.081(0.058)$ & $-0.013(0.037)$ \\
\hline $3^{\text {rd pref Abbott }}$ & $0.249(0.149)$ & $0.302 *(0.125)$ & $-0.641^{* * *}(0.161)$ & $-0.126(0.092)$ \\
\hline 3rd pref Balls & $0.124(0.086)$ & $-0.018(0.076)$ & $-0.166 *(0.083)$ & $-0.085(0.051)$ \\
\hline 3rd pref Burnham & $0.199^{*}(0.098)$ & $0.108(0.091)$ & $-0.501^{* * *}(0.092)$ & $0.081(0.059)$ \\
\hline 3rd pref David Miliband & $0.053(0.082)$ & $-0.029(0.071)$ & $-0.161 *(0.077)$ & $-0.095^{*}(0.048)$ \\
\hline 3 rd pref Ed Miliband & $-0.075(0.090)$ & $-0.030(0.078)$ & $-0.155 *(0.077)$ & $-0.066(0.052)$ \\
\hline $4^{\text {th }}$ pref Abbott & $-0.023(0.111)$ & $0.085(0.101)$ & $0.040(0.102)$ & $0.215^{* * *}(0.062)$ \\
\hline $4^{\text {th pref Balls }}$ & $-0.035(0.092)$ & $0.083(0.082)$ & $0.526^{* * *}(0.078)$ & $-0.005(0.053)$ \\
\hline $4^{\text {th }}$ pref Burnham & $-0.005(0.074)$ & $0.092(0.063)$ & $0.085(0.070)$ & $0.070(0.044)$ \\
\hline $4^{\text {th }}$ pref David Miliband & $-0.073(0.138)$ & $-0.197(0.110)$ & $-0.031(0.131)$ & $-0.231^{* *}(0.083)$ \\
\hline $4^{\text {th pref Ed Miliband }}$ & $-0.064(0.115)$ & $0.044(0.103)$ & $0.460^{* * *}(0.099)$ & $-0.077(0.069)$ \\
\hline Constant & $-4.329^{* * *}(0.473)$ & $-4.592^{* * *}(0.509)$ & $-6.887^{* * *}(0.498)$ & $-3.265^{* * *}(0.358)$ \\
\hline Akaike Inf. Crit. & $337,542.000$ & $337,54^{2.000}$ & $337,542.000$ & $337,542.000$ \\
\hline
\end{tabular}

Since odds ratios are awkward to interpret, Table 2 shows the expected change in vote share for each candidate given a specified change in each independent variable. All other variables are held at their mean, except that the dummy variables for Scotland and Wales are set to zero, and the different endorsement and preference categories are set to their reference level (no preference/ no endorsement).

Change

Abbott endorsement

Balls endorsement

Burnham endorsement
Abbott Balls Burnham Miliband, D Miliband, E

6

$2.7-3$

$-3 \cdot 7$

$-1.9$

0.5

9.1

0.5

$-7.4$

$-2.7$

$-0$

$-0.8$

10.2

$-7.8$

$-1.1$ 
- The influence of legislators' endorsements in party leadership elections

\begin{tabular}{llllll}
\hline Change & Abbott & Balls & Burnham & Miliband, D & Miliband, E \\
\hline David Miliband endorsement & 0.3 & -1.8 & -0.7 & 4.6 & -2.5 \\
Ed Miliband endorsement & 0.5 & -0.5 & -0.7 & -6.6 & 7.3 \\
Cons. vote +1 SD & -0.1 & -0.5 & 0.9 & -0.1 & -0.2 \\
Lab vote +1 SD & -1.4 & -2.2 & 4.3 & 2.5 & -3.2 \\
LD vote +1 SD & -0.3 & -0.7 & 2.3 & 0.2 & -1.4 \\
Scottish seat & -1.4 & 1.3 & 0.6 & -2.5 & 2 \\
Welsh seat & -1.7 & 0.2 & -0.7 & 1.4 & 0.8 \\
$\begin{array}{l}\text { +1 SD more right-wing on taxation } \\
\text { ( }\end{array}$ & 0.7 & 0.7 & 0.1 & -3.7 & 2.2 \\
+1 SD more Euroskeptic & -1 & 1.1 & 2.2 & -0.6 & -1.7 \\
\hline
\end{tabular}

Table 2. Changes in vote share

The value of endorsement shrinks slightly compared to the effects shown in Figure 1. Averaged across candidates, an endorsement now brings an extra 7.45 percentage points. Endorsements (necessarily) cost other candidates: for example, Ed Balls and David Miliband were the chief losers when MPs decided to endorse Andy Burnham. The value of endorsements is large compared to the other changes presented in the table, which often show quite dramatic changes (an increase of one standard deviation in Labour's vote share would win them most constituencies). 
- The influence of legislators' endorsements in party leadership elections

Another way of expressing the value of endorsements is to calculate the smallest change in endorsements which would have altered the result, ignoring the effects on MPs' own votes. David Miliband would have won the election by securing a shift of $1.95 \%$ of the first-preference vote in any section. A single switch of endorsement from Ed to David Miliband would mean a shift of $(7.3+6.6)+(4.6+$

2.5 ) $=21 \%$ in a constituency, or $\frac{21}{632}=0.033 \%$ across the country. (I ignore differences in constituency party size).

To change the election in this section, David Miliband would have needed endorsements from $\frac{1.95}{0.033}=59 \mathrm{MPs}-$ by which time he would have won handily on the basis of MPs' votes alone. Thus, although the effects of MPs' endorsements in this election were important, they could not have changed the result of this close election by themselves.

\section{Conclusion}

I have argued that the effects of endorsement in a closed party primary are large in magnitude, though slightly smaller than the effects of endorsement in primaries in the United States. Although these effects are large, they would not have been sufficient to change the result in the Labour leadership election as a result of the structure of the contest. Since this particular leadership election, the Labour party has abolished the electoral college, meaning that MPs' votes are no longer accorded special influence. This means that endorsements may become relatively 
- The influence of legislators' endorsements in party leadership elections

more important - but also that their effect is harder to identify, since we will no longer have access to the full details of how MPs have voted.

This article has analysed the impact of MPs' endorsements in the 2010 Labour leadership election. It is natural to ask whether the findings of this article also apply to the 2015 Labour leadership election, particularly since that election was won by a candidate with very limited support amongst the parliamentary party.

I have argued that an MPs' endorsement causes a within-constituency increase in the vote share of the endorsed candidate. An increase in a candidates' vote share, unless it is very large indeed, does not automatically lead to their winning the election. Consequently, the fact that very many MPs endorsed candidates other than the winning candidate does not invalidate the findings of this article. Rather, it means that Jeremy Corbyn's success was obtained despite one important factor militating against his campaign.

Given the way in which the system used to elect the leader of the Labour party changed between 2010 and 2015, it will never be possible to replicate the analysis of this article for 2015 data. What data we do have relate to the three categories of voters: party members, members of affiliated organisations, and registered supporters (individuals who are not members of the Labour party nor members of organisations affiliated to the Labour party, but who may nonetheless vote for the leader of the party by virtue of having paid $£_{3}$ for the privilege). Almost $84 \%$ of registered supporters gave their first preference vote to Jeremy Corbyn, in con- 
- The influence of legislators' endorsements in party leadership elections

trast to $57.6 \%$ of affiliated members, and $49.6 \%$ of party members. The differences between these three categories of voters are in part explicable through their different political positions, but the magnitude of these differences is compatible with an endorsement effect of the same magnitude identified here.

Ignoring differences in constituency party size, and taking initial nominations as equivalent to endorsements, then 168 constituency Labour parties were "treated" with an endorsement of a candidate other than Corbyn. If the average endorsement effect is similar, then the Corbyn vote in these constituencies should be $7.5 \%$ lower, and the Corbyn vote across all party members should be $\frac{168}{632} \times 7.5=2 \%$ lower. This would leave six (alternately: thirty-four) percentage points of the difference between party members and affiliates (alternately: registered supporters) to be explained by characteristics of the latter group, and in particular their more left-wing orientation. These differences are likely over-estimates, since constituency parties are larger in areas with sitting Labour MPs, and some MPs who nominated Corbyn did not endorse him. There are therefore reasons to believe that my claim about the effect of MPs endorsements is compatible with the limited data available from the 2015 leadership election, under the plausible assumption that endorsement differences should not explain all of the difference between party members and other voters, since other voters were more likely (for other reasons) to vote for Corbyn.

The 2015 leadership election does of course throw into relief the substantive significance of my findings. I have argued that a candidate who is endorsed by an MP 
- The influence of legislators' endorsements in party leadership elections

will receive a vote share that is 7.5 percentage points higher than the vote share she would have received, other things being equal. On very many occasions, other things are not equal, and it is at least possible that candidates who receive very few endorsements will be able to mobilize other forces which propel them to victory. Certainly, the more leadership elections resemble Labour in 2015, the lower the importance we should attach to MP endorsements. Alternately, the closer the leadership election (and in Britain there are no strong trends in either direction: Denham (2013)), and the narrower the field (both in terms of the number of candidates and their ideological range), the greater their importance. Had Labour MPs been more assiduous in their gate-keeping by not lending their nominations to the Corbyn campaign, the role of endorsements would have been greater.

\section{References}

Arceneaux, Kevin, and Robin Kolodny. 2009. "Educating the Least Informed: Group Endorsements in a Grassroots Campaign." American fournal of Political Science 53 (4): $755^{-70 .}$

Bale, Tim. 2015. Five Year Mission: The Labour Party Under Ed Miliband. Oxford University Press.

Cross, William, and André Blais. 2012. "Who Selects the Party Leader?" Party Politics 18 (2): 127-50. 
- The influence of legislators' endorsements in party leadership elections

Denham, Andrew. 2013. "From Coronations to Close Encounters: Party Leadership Selection in British Politics." British Politics 8 (2): 164-80.

Dominguez, Casey BK. 2011. "Does the Party Matter? Endorsements in Congressional Primaries." Political Research Quarterly 64 (3): 534-44.

Faucher, Florence. 2014. "Leadership Elections: What Is at Stake for Parties? A Comparison of the British Labour Party and the Parti Socialiste." Parliamentary Affairs, Advance Access.

Grofman, Bernard, and Barbara Norrander. 1990. "Efficient Use of Reference Group Cues in a Single Dimension." Public Choice 64 (3): 213-27.

Hanretty, C, B Lauderdale, and N Vivyan. 2014. Comparing Strategies for Estimating Constituency Opinion from National Survey Samples. Working paper, Durham University.

Hanretty, Chris. 2014. "Citizens of Surrey Heath Unite! The Most Left- and RightWing Constituencies." In Sex, Lies and the Ballot Box, edited by Phil Cowley and Rob Ford. London: Biteback.

Jobson, Richard, and Mark Wickham-Jones. 2011. "Reinventing the Block Vote? Trade Unions and the 2010 Labour Party Leadership Election." British Politics 6 (3): $317-44$. 
- The influence of legislators' endorsements in party leadership elections

Kenig, Ofer. 2009a. "Classifying Party Leaders' Selection Methods in Parliamentary Democracies." Journal of Elections, Public Opinion and Parties 19 (4): 433-47.

---. 2009b. "Democratization of Party Leadership Selection: Do Wider Selectorates Produce More Competitive Contests?” Electoral Studies 28 (2): 240-47.

Kousser, Thad, Scott Lucas, Seth E Masket, and Eric McGhee. 2015. "Kingmakers or Cheerleaders? Party Power and the Causal Effects of Endorsements." Political Research Quarterly 68 (3): 443-56.

Lau, Richard R, and David P Redlawsk. 2001. "Advantages and Disadvantages of Cognitive Heuristics in Political Decision Making." American fournal of Political Science, $951-71$.

Masket, Seth. 2009. No Middle Ground: How Informal Party Organizations Control Nominations and Polarize Legislatures. University of Michigan Press.

McDermott, Monika L. 2006. "Not for Members Only: Group Endorsements as Electoral Information Cues." Political Research Quarterly 59 (2): 249-57.

Milner, Henry. 2006. "The Determinants of Political Knowledge in Comparative Perspective." Scandinavian Political Studies 29 (4): 386.

Pemberton, Hugh, and Mark Wickham-Jones. 2013. "Brothers All? The Operation of the Electoral College in the 2010 Labour Leadership Contest." Parliamentary Affairs 66 (4): 708-31. 
- The influence of legislators' endorsements in party leadership elections

Van Biezen, Ingrid, Peter Mair, and Thomas Poguntke. 2012. "Going, Going,... Gone? The Decline of Party Membership in Contemporary Europe." European Fournal of Political Research 51 (1): 24-56.

Wittman, Donald. 2007. "Candidate Quality, Pressure Group Endorsements and the Nature of Political Advertising." European fournal of Political Economy 23 (2): $360-78$. 